\title{
ワルシャワ大会に出席して京都大会にのぞむ*
}

$$
\text { 稲 垣 道失 }
$$

はじめに

1969年 IIW 年次大会はいよいよ日本で開催されるこ とになり，国立京都国際会館で 7 月 12 日（土）加ら 7 月 19日（土）まで各種の会議が行なわれる。また会期中は 工場見学, Reception, 宴会, 催し物の見学などがあり， 7 月20日（日）加ら23日（水）の間には会議後の旅行打 よび見学がある。一方，7月19日（土）から24日（木） まで東京晴海の国際留易センターで国際的な Welding Show が開催されることになっている.

ワルシャワにおける1968年 IIW 年次次会は，7月 13日（土）加 7月20日（土）まで, 各種の会合とし て Governing Council および Executive Council の会 議, 開会式, Houdremont Lecture, Public Session, Commission I の Colloquim, 各 Commission とその Drafting Committee の会議，国別会合がそれぞれ行な われた。 また会期中は工場見学，National Museumに おける Reception, Grand Theatre に打ける民族舞踊 “Mazowsze"とオペラ“Halka" の観劇, Banquet (宴会)，それに同伴者向けの見物があった．7月21日 （日）加ら26日（金）の間には，会議後の旅行が 3 班に わかれて行なわれた。一方，てれらの期閭中ワルシャワ の工業大学の 1 室で簡単な Welding Show む開かれて いた.

国際溶接学会 (International Institute of Welding, 略して IIW）の事務局では，年次大会を開催するための 組織と運営についての覚書を作成して扔り，その方針に もとづいて計画されるので, 京都大会もワルシャワ大会 と大体類似のプログラムによって実施される。したがっ て,ワルシャワ大会の決定事項が京都大会で実行され， またワルシャワ大会の模栐が京都大会の開催に参教にな ると考えられる。

編集委員会加ら私に「ワルシャワ大会に出席して京都 大会にのぞむ」と題して執筆するよう要請があり，総務 関係では原案作成化成田图郎氏らが大変尽力されてお り，私としてはとくに学術上の問題について，ワルシャ ワ大会などの経験と京都大会に対する私見を高のこらな い気持ちで書きたいと思う。

\section{IIW と京都大会}

本誌の昨年 1 月号に，1969年京都大会のために IIW

*原稿受付 和和 43 年 11 月 2 日

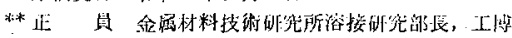

の活動状況の特集が揭载されており，こてで IIW の詳 細を記述する必要はないと思うが，IIWについて私が 二，三気付いた点を述べる。

\subsection{IIW $の$ 目的亡意義}

まず，私どもが発する質問は，“IIW はどんな目的を 屯っているか?"ということであろう.

IIW の定款を要約す机ば，IIW の目的はあらゆる方 法で溶接の進歩を促進することにあるとし，乙のため (1) 溶接関係の科学技術の情報を交換する，(2) ISO（国 際標準化機棈）に協力して溶接関係の国際規格の制定に 努める，(3) IIW を通じて各国の統一的見解を求める， (4) 定期的な集会を開催するというととになっている.

IIW は 1948 年に発足いらい今日まで 20 年間等年着実 飞年次大会を開き，また各 Commission ではそれぞれ 中間会議を開いてきている．学術的な国際会議はたくさ んあるが，IIW のような長い伝統之每年開催の国際会議 は，ほがあまり例を見ないようであるＩIW は多くの 国際会議がそうであるように，当初西欧諸国を中心組 織され，それに東欧諸国や日本などが加盟して，名実之 もに世界的な規模になったわけであるが，現状は西欧ブ ロック，米ソの二大勢力，それに日本などと各ブロック ごとの色彩が強まってきた感じである．とくに日本の場 合，独りアジアに個立してに゙ての国ともいろいろの意味 でつき合っていかなければならない国として，微娶な立 場に置かれていることに気付く，私は溶接応用の他の 二，三の国際会議にも出席して，その感をますます強く 持ったのである，諸外国の人々の日本に対する認識はま だまだ溥い。

こうした意味からも，日本で IIW 年次大会が開催さ れる運びになったことは，きわめて意義のあることであ る.乙の機会に，諸外国の参加者に日本をよく見せてよ く認識させることである，てのためには京都，奈良，富 士山，げいしやあ結構であるが，それよりあ日本の近代 的な都市，交通，工場および研究施設などをよく見せる べきである，とくに，溶接に関係の深い世界的に優れた 鉄錻，造船，車両，溶接機材などの工場招上び溶接研筑 機関を見学させるべきであろう。

\subsection{IIW とその年次大会の効果}

つぎにだれしも発する質間は，“IIW にはごんなメリ ットがあるか?”というととであるう。 


\section{（1）情報交換}

上述の IIW の目的にもあるように，溶接関係の科学 技術の情報を交換するこ之は，わが国の溶接の発達を促 進することになる，わが国の溶接技術はここ15年ほよ゙の 間にいちじるしく発達し，いまや構造用鋭を中心にした 溶接技術は世界のトップレベルにあるが，乙の開発実用 化は残念ながら日本独自の研究によってなされたすのと はいえない，想えば，1947年までの第 2 次世界大戦中の 科学技術の銷国時代を経て戦後蓋をあけて見て，日本は 欧米諸国の溶接技術の進歩の格差に擎かされたわけであ る. わが国が IIW 年次大会江出席し始めたのは1952年 からで, 初めのころの出席者の数は数名にすぎなかった が，1959年加ら急激化增加して約20 40名の多数が铮年 出席するようになった。そして 1968年までに約 350名の 日本人が IIW 年次大会に出席し，溶接科学技術の情報 を交換するとともに，乙の機会を利用して各国を歴訪 し，諸外国の優れた溶接技術をわが国へ導入してきた。 ここ数年前までは，IIW 年次大会か開催されるたびに， 一つや二つの外国の新技術を見て警加され，日本傜持ち 帰ってその適用を試みるなどして，世界水準の溶接技術 を追いかけるような状態であったが，最近ではIIW 年 次大会に出席してもそれほどめずらしいものはなくなっ た．これは日本が現状では多くの面で世界のトップレべ ルになってきたためであるが，それだけに今後の日本の 溶接技術のあり方についてじゅう分考えるべき時期侄到 来していると思う．いまや日本は，ある面では世界の先 頭に立って指導的な役割を果さなりればならない，した がって，現在では私どもはIIWに対して従来とはいく らか違った目で検討する必要があるであるう。

わが国の今日の溶接技術の進歩は，IIW などを通じて 諸外国の溶接関係の科学技術の情報を入手し得たてとが 一つの大きな原動力となったと思う。乙れは日本にとっ て大きなメリットと考えるが，IIWに対しては消極的な 立場である，今後の日本はIIW に対して積極的な立場 で提案し，日本の意見が IIW に強く反映しなければな らない. 1969年の京都大会はそのよい機会であり，これ を契機にして日本の立場は強くなるであらう。またその ように努力しなり垈势らない。

\section{(2) 国際規格}

IIW では溶接関係の国際梘格の制定に努力している が，国際的な䙺格や規集について検討与る場合，定常的 な作業を進めているそれぞれのCommission 亿各国の 意見が出される.そしてどの意見が採択されるかは，そ の国の目に見えない実力と委員長らの意向によることが

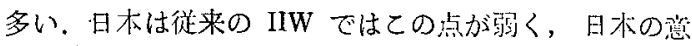
見はそれほど棈極的に出されることが少なくまた採用さ
れることあ少なかった。しかし，国際規格や規準は日本 の経済や貿易に直接ひびいてくるむので，日本の会社が 外国の会社と取引きする場合に，てれらの規格，規準で 泣かされたことむしばしばであった．したがって，国際 規格や規準はその国や会社にとって重大な影響を与える あのであって，決してなおざりにはできないあのであ る. 従来，わが国が外国之取引きする場合，米国規格や 西欧の挸格によって枋料が製造され溶接構造物が製作さ れることが多く，またこれらの規格が国際規格に強く反 映されている。こうしたととを IIW やその他国内外の 委員会で経墟して，日でろ私は残念偲っている．日本 の場合，地理的ならびに言語の恶条件があるにしても， 昨今の高速時代にあっては，乙れらの悪条件む突破でき るものであり，またこれらの条件がかえって幸いすると とがあるかす知机ない，いずれ化してあ栍極的な方策を とるべきであろう。

\section{（3）日本の統一的見解}

IIW の目的の一つに, IIW を递じて各国の統一的見 解を求めるというと之がある．わが国の溶接専門の学協 会としては，周知の上うに溶接学会と日本溶接協会があ り，そのほか溶接に関係する学協会は非常にたくさんお って，わが国全体として溶接関係の学協会はよくまとま っているとはいい得ない.IIW に刘応する国内機関とし $\tau$, JIW (日本溶接会議, Japan Institute of Welding) が設置されており，IIW の Member Society として登 録されている溶接学会、日本溶接拹会，溶接研究所於よ び日本学術会議の 4 団体の横の連絡をとるようになって いるが，乙れもじゅう分上はいえない，日本の溶接関係 の学協会の態勢は加なり複䧴多岐になって扔り，すう少 しすっきりした態勢が望まれるところである。これは IIW に招いてわが国の統一的見解を述べるためにあ必要 なととである．乙の問题す京都大会をきっかけとして， よりよく好䎐するととを期待するものである.

\section{（4）研究態勢について}

それ之同時に，私はわが国の溶接研究の態勢について 熟考を要する問題と考える. 前述したように，いまやわ が国の溶接技術は多くの面で世界のトップレベルにあ

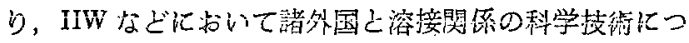
いて対等に情報交換を行ない，またある面においては指 導的な役割を果すべきときにあたり，わが国独自の溶接 研究によって開発奉用化を進めなりればならない，この ための溶接研究の態勢が, 現在整っているであろうか.

私は1968年 6 月28日から 7 月26日までの29日間, 西欧 4 ケ国(イギリス，西ドイツ，フランス，ルクセンブル グ) と東欧 4 ケ国（東ドイッ，ポーランド，ソ連，子ェ コスロバキヤ）を逗り，西欧側ではルクセンブルグにお 
ける E. C. S. C. (European Communities for Steel and Coal）の第 4 回会議に，日本からの招待者として「高圧 設備に㧍ける高張力鋼の利用」と題して論文を送り討議 に参加した. そのあと東欧側の IIW ワルシャワ大会 K, Commission IX とXII への2つの論文を持って出 席した。 また BISRA の治金研究部 (Sheffield), BOC 溶接研究所拉よび BOC-Airco 化工機工場 (London), Technische-Hochschule Hannover の材料研究所 (Hannover), BASF の高圧プラント工場 (Mannheim), SGN 社の原子力設棓部 (Paris), SAF 社の溶接センターおよ び Pont de Maxen 化工機工場 (Paris とその近效),

ZIS 中央溶接研究所 (Halle), Technische-Hochshule Magdebug の溶接研究所 (Magdeburg), Welding Show (Warsaw), Huta-Warzawa 特殊堸工場 (Warsaw), E. O. Paton 電気溶接研究所 (Kiev), Moscow Univ. (Moscow), VUS チェコ溶接研究所 (Bratislava) を見 学した。

今回の渡航で幸いであったことは，西欧と東欧の様子 を同時期に見聞するてとができたととである，西欧と東 欧の溶接関係の研觉所の機構組織はそれぞれ著しく暴な るが，基礎から開発実用化までの過程を進める上にをれ ぞれきわめてよくできているように考えられた，すなわ ち，西欧側の溶接関係の中立的な多くの研究所，たとえ ば BWRA やフランス溶接研究所, それに铁錻関係の BISRA, IRSID や Max-Planck 研究所などはその国の 溶接協会あるいは鉄鋼協会が資金を出して創設し，協会 の会員会社が共同で出資して維持しているようで，会社 の共通的な問題はその国の公的な立場で試験研觉を実施 し，特定の問題とくに process の開発研呪などは特定 の会社の委託を受けて，これらの研究所の特定の group が秘密を守って研究を行なう。開発研究の成果が期待 される適当な時点で, 問題を委託した会社が研究所の開 発した研究者之組んで実用化に乗り出す仕組みになって いるようである。また，西欧僛の著名な溶接機材会社 では, 自力で溶接研究所を持って溶接機材の開発を行な い, 同所内あるいは別の溶接センターで実用化試験と作 業者の訓練を行なっている.そしてさらに同系の施工会 社を設立して，てれらの機材を実用に供している。一方 東欧側の溶接研究所として有名な E.O. Paton 電気溶接 研多所，VUS チェコ溶接研究所，ZIS 東独中央溶接研究 所などはすちろん国立で中央集権的であり，研究所にた くさんの人員をようし，基礎研究加開発実用化まで所 員によって一貫した仕事ができる組織になっている。

その例を，溶接関係の研㠰所として世界最大といわれ るソ連のパトン研究所によって，つぎに説明しよう。

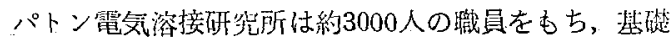

研究と開発研究の成果を国の座業経済に直接導入するた めの活動的な構成組織になっていることが特長である. このため研究所にはつぎの主要な部門がある. (1)研究部 の研究室 : 基礎研究, 開発研究および実際問題の钊告の 作成，(2)技術部：溶接技術の解決と仕様書の作成，(3)設 計部：新技術を生産に適用するための機械装置の設計，

(4)夷験プラント部：溶接機材の製造，技術研究局：国 の産業経済に導入するための量産体制の組織化，(6情報 部：文献の調查と報告.

研究成果を生虐に導入することは，もっとも重要なと とであるので, 各部門はたがいに緊密な連けいをとって その日標に進み，研究者は適当な時点で企業の協力を求 めて技術基準を作成する。そして仕事の内容によって は，研究所の種々の立場の人々が関連のプラントや工場 に長期間出張する．したがって近年では研究所員の約 $1 / 3$ が，平均して彼等の仕事特間の60〜70\%をプラントや組 立て現場で過すようになっている，各種分野の企業にお ける生産に新溶接技術を導入するために，設計部と技術 部から榡成される実験的設計局が活動している。

パトン研究所の企画には大きくわけて $2 つ$ つ，その 1 つは研究計画で他の 1 つは実験的に工業上のチェック を行ない研究成果を導入する計画である。研究計画はす べての部門と研究室で作成され检討される，研罗所の指 導会議が每月 1 回開かれ，そとで技術者执よび研究者の 仕事のプランをチェックするようになっておりままた のプランは各部あるいは研究室の全員集会で所長あるい は副所長がチェックする，完成したテーマの報告は各研 究室と部門の七ミナ一，所長の招集する会議およびその 研乫に與味を示票業所で行なわれる。当研究所の構成 は科学者，技術者，技能者㧍よび作業者からなり，博士 が15人， candidates of science 上よばれる有能な研究

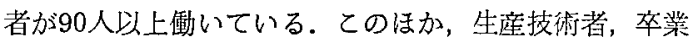
論文作成のための学生，大学院制度の研究者がいる．研 究所の研究者の平均年命は30才を少し越えた程度であ る.

以上のように西欧側之東欧側の溶接関係の研究所の棈 成組織はそれぞれ特徴があるが，ひるがえってわが国の 現状を見ると，明らかに西欧的である．しかし国として の総合力に汒しいことに気付く，わが国の場合，企業が 合併して大企業化する傾向があり，それぞれの大企業の なかではかなりまとまった研究開発実用化の態勢がとら れているようであるが，企業間の競争がはげしくまた外 国からの技術導入の問題などああって，各社がうちにこ ある傾向がある。一方，中立の研究機関では人員に之し く公表のたてまえから，小人数の小さな試験的研究に上 よ゙まるととが多い，というようなわけで，おたがいの研 
究が個立化して，総合的な研究開発害用化の一貫した流 机にひどく欠けているように思う。いまや技術勒新のテ ンポは急ピッチであり，またビッグサイエンスとよばれ る原子力，宇宙開発あるいは海洋開発があって，国内的 な統一体制之対外的な競争力の強化が痛感される次第で ある、IIW の京都大会をひかえて，ての点についてす今 後の検討が必要であるう。

\section{(5) IIW での活動}

IIW は営利之無関係で純学問的あるいは技術的な問題 を討議する組織であるので，各国の中立的な罒体が加盟 し，会社や個人が直接参加していないが，会議は常設の 技術委員会 (Technical Commission) の活動が 毛体と なり，定常的な作業と科学技術の情報交换をしている。 各技術委員会の委員長やそのむとに置かれた小委員会の 委員長および各国の代表者（Delegate）は定常的代きま って扔り，て礼らの人々が常時会議に出席することがた て前になっている．また，各国の研究者が各国の加盟団 体から推せんされて出席し，プログラムにしたがって研 究発表を行ない討論化加打るようになっている。 日本の 場合は従来地理的条件などによって，常時登録された代 表者が铂年会議に出席することが困難で，代理者が出席 することが多くまた Expert やObserber には新人が大 多数である。したがって，会議の主導的役割を演ずると とは言葉のハンデイもあってむづかしいが，各人の心が け一つで䅡極的に話かければかなりの線までいけるもの と考元る.

\section{（6）個人的なつながりと国際間のつながり}

IIW の会議に出席してとくにメリットのあるととは， 諸外国の溶接専門家と個人的な知己を得ることであると 思う。私はいまから 8 年前の1960年に, ベルギー・リェ 一ジュで開かれた IIW 年次大会に初めて出席したが, 当時話し合った人々がワルシャ、ワ大会に出席していて, たがいに顔を合せば，思い出して再会を喜び合うととが できた．各国の出席者はたとえ国悄がちがっても，個人 同しのつき合いになれば，同じ人間である以上その心悄 は変らないものであって，紙の上の平面的な情報交換で なくて生きた気持ちの通い合いができるあのである。し

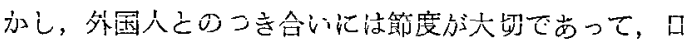
本人は日ごろ外人との接触が少ないために，之かくこと さら自分を早下したりあるいは逆纪排他的になる傾何が あるが，対等の態度で堂々之振舞えばてとたりるもので ある．多くの日本人は外人之会ってまず言葉のハンディ を感ずるが，外国人であってもその国へ行けば大多数の 人々が他国語を知らないわけで，言葉は経験之訓練と気 持によるものである．IIW の会議にいつも出席してい る常速は，経験によっで言葉がうまいのが当然で，何も
気拉くれする必要はない，言葉に不馴れな私どあは少な くとも気持ちの上で優位に立つよう心脚けるべきであ る.

京都大会では各技術委員会の走常的な日本の Delegate がすべて出席されることであるうし，各個人もとの機会 に JIW の各刘応する委員会を通じてできるだけ多数出 席される上う願うむのである，乙のためには関係会社の 深い御理解之組織委員会の可能なかぎりの妈置が必要で ある．京都大会に扔けるわ机わ机日本人の寄与之多くの 外园人専門家との知已学得るととは，個人的な問題では なくて，ひいては日本と外国の会社間の耿引き汇連か りままたIIW における日本への認識と地位を高め，国 際的な䙺格や規準の制定にあたっては日本の発言が強く 反映されるようになるであるう。

\section{2.ワルシャワ大会における決定事項}

\subsection{IIW の現状}

IIW の組織構成は，会員 (Member Society)，理事会 (Governing Council), 悻行委員会 (Executive Council), 技術委員会 (Technical Commission) 拉よび事務局から なって抢り，IIW の運営方針は年次大会の初日上最終日 の2回開催される理事会において正式に決定される.

理事会は各国の 3 名以下の National Delegate で構 成され，わが国の National Delegate は現在，他教 授，木原教授执よび小林教授の 3 人になっており，ワル シャワ大会の理事会にはで 3 人とも出席された，執行委 員会は会長，副会長 ( 6 人)，盼務幹事，科学技術幹事 (Scientific and Technical Secretary) および事務総長 (Secretary General) で構成され，IIW の運営の権限 上任務が課せられており，IIWの運営方針は必要に応じ 随封開催されるこの執行委員会でお膳立てされて理事会 に報告される。

現在の IIW 会長はアメリカの F.L. Plummer 氏で, 彼が京都大会の終了まで勒めるが，それ以後 3 个年間の 次期会長にベルギーの W. Soete 教授が選ばれた，副会 長は 6 人で構成され，1969年の京都大会をひかえてわが 国加らは1967年〜1970年の任期で伸教授が任命されてい る.その活かスエーデンの B. Kjellberg とソ連の N.N. Pykalin がワルシャワ大会で満期となり，かわりにスイ スとルーマニアが副会長に新任された。な拉，1969年京 都大会以後の年次大会開催地は，1970年がスイスのロザ ンヌ，1971年がスエーデンのストックホルムに決った。 IIW の会員としては，ワルシャワ大会加ら新たにアイル ランドが 1 国追加され，33ケ国63罒体之なった。

IIW の盼政は主として各国からの会費でまかなわれて おり，その会装は国を単位として罗本会提50ポンドとそ 
の国の鉄鋼生産量の等級および加盟団体数によって算出 される．わが国の場合 1968 年度は 425 ポンドであった が，1969年はポンドの值下げなどの影響のために総体に 值上げとなり 550 ポンドとなった，わが国法鉄鈵生座量 の等級が米，ソ，日，独とも同額となり，加盟団体数が 多く4であることから算出され，結局日本はり連の610 ポンドについで世界で 2 番目の多額納入になっている. なおそ扎以下はアリカ520ポンド，西独460ポンド，英 国375ポンドの順になっている。

\section{2 技術委員会の再編成}

IIW の技術委員会には16の委員会と 1 つの Study Group が常設されてれり，技術的な問題を定常的に取 扱っているが，ワルシャワ大会の理事会で合後の委員会 の活勳分野の大巾な再編成が行なわれたことは注目す心゙ きととである。とくに大きな改編は，新 Commission IV が編成されて Special welding processes となり，従来 の Commission I のなか力口 welding by mechanical energy をとしに移し，还来の Commission III のなか から micro-welding を新 Comm. IVに移し，また旧 Comm. XII の Sub-Commission XII D だ取扱っていた “Other special processes”を移したことである。 そし てこの新 Comm. IV の新 Chairman には西独 Aachen 工科大学の F. Eichhorn 教授が任命された。なお ID Comm. IV $の$ Documentation はIF Comm. VII Standardization と合体して新 Comm VII になった. このようにして溶接法関係の各委員会は，今後つぎの活 動分野を取报うよう決定された。

Commission I-Gas welding, Brazing and Cutting :

Gas welding, brazing, soldering, metal spraying, thermal cutting, thermit welding, welding with a soldering iron.

Commission II-Arc welding :

Arc welding with covered electrodes, stud welding, arc welding with bare electrodes (stick electrodes).

Commission III-Resistance welding:

Resistance welding, friction welding, induction welding, welding by condenser-discharge, welding with high-resistance electrodes.

Commission IV-Special welding processes:

Electron beam, laser, plasma, explosion, impact, diffusion, ultrasonic, cold and forge welding, micro-welding.

Commission. XII-Flux-and gas-shielded electrical welding processes :

Submerged arc, MIG; TIG and : electro-slag welding, welding using a rotating arc, arc welding between carbon electrodes, atomic hydrogen welding, carbon arc welding, arc welding with bare electrodes (continuous electrodes).

この改編に伴って，わが国の JIW の各委員会の構成 を検討する必要がある。

技術委員会は年次大会において, A A Bの 2 グループ にわけられ午前と午後にわかれて会合するが，今回の新 編成による各委員会のグループわけはつぎのとおりにな った.

A Group : Commissions I, II, VI, X, XI, XIII, XIV, XVI

B Group : Commission III, IV, V, VII, VIII, IX, XII, $\mathrm{XV}$

ここで，たがいに関運の深い Commissions III, IV お。 よび XII が同じ Bグループに属し，同一の壯閻に会議が 開かれるととは，関係者が会議に出席するときにきわめ て不便である、これについては，ワルシャワ大全の理䂇 会や各関係の委貝会で大いに論議され反論も多かった が，執行委員会の意向が強くて，強引に押し切られたか たちである。

IIW の事務は事務総長 (Secretary General) の P.D. Boyd（イギリス）上科学技術韩事 (Scientific and Technical Secretary) の A. Leroy（フランス）の雨者 によって管理統括されており，事務局は事務総長の所属 するイギリスの溶接学会内に置かれている，わが国に秥 ける1969年京都大会の計画についてむ，IIW の事務局と じゅう分連絡をとる必要があり，ワルシャワ大会開期中 小林，成田，立木，渡包(日本学術会諩関係者) が P.D. Boyd 事務総長任面談し, 京都大会の計画や運営につい て種々打合せを行なった。

\section{3 . ワルシャワ大会の模様と 京都大会への反省}

ワルシャワに打ける1968年々次大会には24ケ国から 約 720 人が参加し， ポーラント人年含めると約 1000 人吹 上にのばり，その予算総額は約 16 万ドル (5,760万円), 準借作業に従事した專務局員 41 人であったとのことで ある. 日本からは 40 人が参扣し, IIW 副会長仲教授, Commission X の Chairman 本原教授をはじめ, 日本 の出席者団長小林教授，副河長金沢教授ならびに稻垣， 幹事成田上, 各 Commission の日本代表として市川, 三上，中村 (孝), 鈴木 (妓) らが出席した。

\section{1 ワルシャワ大会出席のための準備}

ポーランド組織婪員会 (Polish Organising Commi- 
ttee）からの案内状としては, 1967 年 8 月に Circular No. 1 (ワルシャワ大会の計画の簡単な目次を示した招 待状）と 1968年 1 月に Circular No. 2 (ワルシャワ大 会の詳細計画之参加申込み手続きを示した回状）が届 き, 各人の参加申し込み (Enrolment) を 1968年 4 月 5 日までに行なった. Enrolment Form に記入するにあた って, 各人の Passport No. を記入する欄があったが, これはこの時点では不明であり記入することは不可能で ある. 参加申込みと同時に, Enrolment Fee 30 , ホテ ル予約料, 各種行事参加費をドルで支払わねばならない が，まずは日本の旅行社を通じて立替えをしてあらっ た. 今回は日本溶接協会の骨折りで, 溶接技術調查団が 編成されそのサービスを“西鉄航空” が受けもつととに なった. 一方, ポーランドの旅行社は“ORBIS”が一本 化してやっており, その日本の空口が “日本交通公社” になっているので, 申込み手続きは西鉄航空を通じて 日本交通が ORBIS とコンタクトする方式をとった. 参加申込み後, 5 月 28 日付でポーランド組織委員会の Secretary から各人に registration number と宿泊ホ テル名および所在地を通知してきた. また同時に, 私の passport number と到着日時を問合せてきたので，決 定次第旅行社を通じて連絡をとった。

\section{2 ワルシャワへの入国}

以上のような出発前の手続きがあって, 私は 7 月 14 日 （日）東ベルリンの Shönefeld 空港から単身でポーラン ドの Flight LO 246 機に搭乗して, 予定より 1 時間おく れで夕方18時ごろワルシャワ空港に到着した. ワルシャ ワ空港の入国審査空口には, 各出席者の到着日時, 便 名, passport number のリストが用意されそれと照合 されるので, 入国審査は行列のため約 1 時間ほどかかっ たが，大体順調にすんだ. 税関検査を通過して，いくら かの Money changeをしてから, ORBIS の係員の指示 で配車バスに乗り各自のホテルに着いた. ホテルの玄関 には ORBIS の Congress Service Office が特設されて いて $2 \sim 3$ 人の係員が配置されていた. ここでは Hotel, Special Event, Tour, 出国の際の Transportation な どの Registration がなされ，きっぷなどが渡された. この時に, Enrolment の際払い込んであった Hotel 予 約料のうち食事代が同国の通貨 (zlotys) で払いもどさ れた. このホテルでの ORBIS の登録手続きで 2 時間も かかり, ホテルの自室に入ったのは21時でろであった. その晚は疲れて夕食抜きで入浴後すぐ寝た.

ORBIS は Hotel, Transportation, Tour などの Service 関係を一手に引受けて処理, また Enrolment Fee の処理を行なった. ORBIS の入国時の手配は形式 的には一応よくできていたと思うが，事務能率の面で問
題がある，とくに，ホテル玄関における手続きでは，係 員が 3 人も拈りながらそのうちの 1 人が出席者と応待し ているだけで, 他の 2 人は電話をかけたり立話しをした りしていた，われわれ出席者は列をつくって立って待っ ていた. 列の私の前に数人いたが, この数人の処理に 2 時間むかかるようでは困る、私の前に並んでいた出席者 が私を見て，舌打ちし日本ではこんなととはないだろう という意味のととをいっていた，出席者は皆遠路疲れて 到着しているのであるから，乙の場合整理券であ臨時に 渡して事務処理し, 翌朝にでも登録ずみのきっぷ類を随 時手渡したらよいと思う. 入国直後の手続きのまずさは 第 1 印象を悪くするので, とくに相手の気持ちになって 細かく配慮することが大切であろう.

ホテルでの ORBIS の登録手続きが終ると連絡カード が渡され，乙れを持参して Reception Center Office（主 会場のワルシャワ大学内）に行き, 大会出席の Registration を行ない, Packet を受領して登録が完了する が, 私は 7 月 15 日（月）の開会式当日これを行なった 開会式などは主会場のワルシャワ大学から徒歩15分位の National Philharmonic Hall で開催された. 私はワル シャワ大学での登録に手間どり, また National Philharmonic Hall への案内や配車のバスもなかったので 道に迷い, 10時からの開会式に大分おくれて出席した. (写真 -1 ).

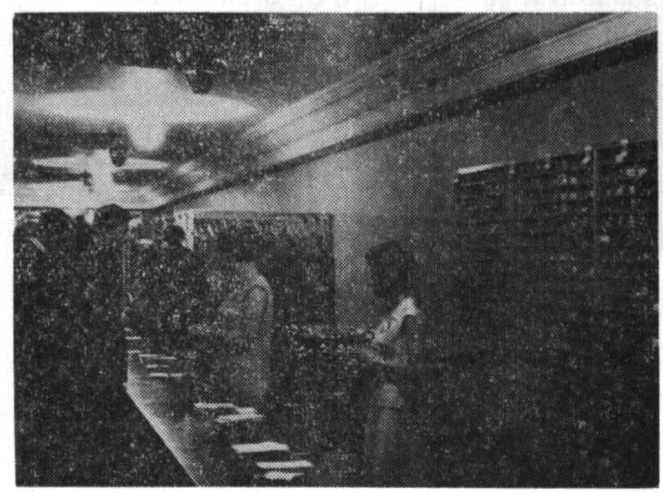

写真－1 開会式場 (National Philhamonic Hall）における受付

京都大会では, 登録や諸会議が一括して国立京都国際 会館 (Koyto International Conference Hall) で行な われるので, 当日会場でまごつくことはそうないと思う が, 羽田空港や京都駅での案内, 京都における案内之配 車, 登録事務の能率と正確さ, 会場の設営などにはじゆ う分注意を払う必要がある.とくに，日本の組織委員会 の事務局之国立京都国際会館が東京之京都に離れている こと, 京都国際会館が京都のなかで不便な地域にあるこ 
となどの地理的悪条件からくる種々の連絡, 輸送の問 題についてはあらかじめじゆう分考慮しておくべきで あろう。たとえば, 大会直前までに IIW 事務局, 各 Commission の Chairman, 各国からの出席者などから 種々の郵便物が送付されてくるであろうが, その送付先 の指示や郵便物の整理取扱いなどを明確にしておくこと あ大切であろう. 京都大会では. Hotel, Transportation, Tour などの Service 関係は日本交通公社が担当すると とになっているが, 組織委員会との緊密な連けいが望ま れる. 要するに, 遠路はじぬてやってくる多くの外国人 が京都大会に円滑に出席できるよう, 彼等の身になって 言葉と地理を克服できるように親切な処置がとられなけ ればならない。

\section{3 開会式 (Opening Ceremony)}

開会式は 7 月 15 日（月） 10 時加ら 10.45 分まで, National Philharmonic Hall (写真一2) で行なわれ

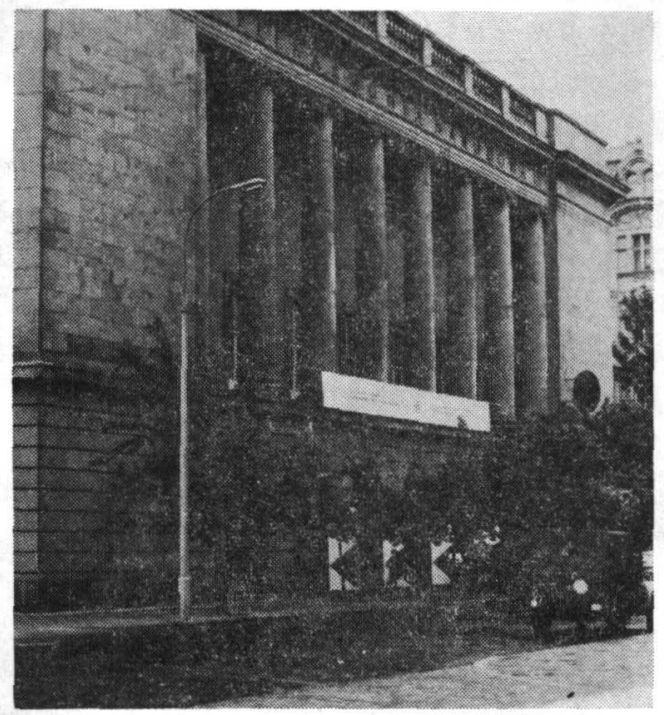

写真一2 ワルシャワ大会の開会式, Houdremont Lecture, Public Session および Colloquium が行なわれた National Philharmonic Hall

た. 式次第は各代表者の Speech が主体で，1）ワルシ †ワ大会組織委員長 Mr. J. Pilarczyk (Gliwice 工科大 学教授)，2) Patronage の Mr. E. Szyr (the Deputy Chairman of the Council of Ministers, 科学菠術委員会 会長)，3）ワルシャワ市長 Mr. J. Majewski，4）IIW 会長 Mr. F.L. Plummer の順で行なわれた. ことでとく に Plummer 会長が日本の hospitality を強調して京都 大会に期待を寄せたととは印象的であった，また東京晴 海における International Welding Show についても 興味を示した。開会式ではさらに Edström Medal の表
彰が行なわれた。これは IIW に対する貢献者を表彰す るために1966年から W. Edström（1960 63年の会長, スエーデン ESAB 社長) の基金によって制定されたあ ので, 今回は二代目（1951 54 年）会長であった Prof. H. E. Jaeger (オランダ) に渡された. 本来ならてれは京 都大会で渡される予定であったそうであるが, 彼が出席 できないという理由で 1 年さか上ってワルシャワで渡さ れたものである. 彼は日本の溶接学会の外国人名誉員で ああるので, 小林会長があとでお祝いの言葉を述べた. なお今回の受彰者は 3 人目で, 第 1 回 (1966年) が W. Edström 自身の子息 Mr. G. Edström に与えられ，第 2 回(1967年) が IIW の創立会長の Mr. P. GoldschmidtClermont に与えられた.

会場の National Philharmonic Hall は立派な建物で あり，玄関には IIW 年次大会の飾付けをした柱が立っ ていた。.またてれらの柱には, 中央が黒くて周囲が赤か ら黄色に変るようなアークを連想する模様が画いてあ り,なかなか印象的であった．しかし，道順の案内が少 なく, 式場では揭示ゃアナウンスがなかったので, 出席 者は大分迷った。

京都大会では組織委員長の岡田阪大総長, Patronage, 京都市側代表, IIW Plummer 会長らの挨捘があろう. ところで, IIW の公用語は英仏の二国語であり, 開会式 の挨抮では主催国の国語を使ってもよいととになってい るが，日本の場合英語が主体にならざるを得ないであろ う．この場合できるだけ同時通訳が望ましいが，仏語の 通訳が問題である.また案内，掲示，アナウンスにあじ ゆう分気を配る必要がある.

なお，IIW 年次大会では閉会式は行なわない慣例にな っており, 会議の最終日（土）は Coverning Council と Executive Council でしめくくり, あくる日からは Post Assemby Tours などが始まる.

\section{4 特別講演について}

IIWの特別講演にはHoudremont Lecture 之 Porterin Lecture があり, 毎年交互に行なわれる. Houdremont Lecture は西ドイッの E. Houdremont（1956～58年 副 会長）を記念する講演で, 1960年リェージュ大会から設 けられ, W. Soete, M. Cohen, G. Vedeler, A. A. Wells, W. Hoffmann の各氏が講演した. Portevin Lecture は 1963年ヘルシンキ大会から設けられ, A. Leroy, G. A. Homes, B.E. Paton の各氏が講演した. ワルシャワ大 会では Houdremont Lecture が行なわれ, 東洋からは じめての講演者として木原教授が選ばれた.

木原教授の Houdremont Lecture は開会式の直後同 じ講堂で11時15分から13時まで約 1 時間半行なわれた. このときの司会者は, Commission IX の主催のためそのの 
Chairman Mr. H. Granjon であった. 演題は “Welding Cracks and Notch-Toughness of Heat-Affected Zone in High-Strength Steels” で, わが国の高張力鋼の溶接割 れと熱影響部の切欠じん性に関する研究を紹介したあの である. 溶接割れについては，主として金材研，阪大お よび川重の低温割れに関する研究がまとめられ，切欠じ ん性については船研および日本溶接協会鉄鋼部会のデー タがまとめられている．木原教授はスライドを使い，終 始落付いた態度で堂々と英語で講演され, 会場を埋めた 500 人以上の出席者に, 深い感銘を与えた.なお，テキ ストは当日配布になった.

この日は講演だけで質問などは行なわれなかったが， 別の日の 18 日（木）午後 2 時〜 3 時まで, Commission IXとXの Joint Meeting で Houdremont Lecture につい ての Discussion があった. 各国からの質問は当日朝ま でに木原教授まで交書で提出することになり, 昼でろに 6 件ほどの質問状が届いた。 その内容は Mr. H. Granjon から 3 件（遅れ割れの incubation time の求め方, 熱影 響部のかたさとマルテンサイト量が低温割れに及ぼす影 響が被覆アーク溶接以外の溶接法に対しても適用できる かどうか，TRC 試験における応力と割れ発生時期との 関係), Commission IX の Sub-Comm, G. の Chairman Mr. G. Kullberg (スエーデン) から炭素当量について 1 件, Mr. R. W. Nichols (イギリス) から高温割れとく に応力除去焼なまし時の割れについてと切欠じん性に ついての 2 件であった. ほかに Discussion の場で Dr. Rose や Komers (西ドイツ) らの即席の質問があった. 私は木原教授加ら当日午前の Commission XII の会議中 に 5 件の割れ関係の質問状を渡され，昼食抜きで Hotel に帰り住金の伊藤氏の援助で約 1 時間半てれらの回答書 の作成に専念した．私としてての種のととはいまだかっ てない苦しい体験であった。しかし, 時間が足らなくて あと 1 問の回答が未完成のまま, ワルジャワ大学の会場 へ14時に行き, H. Oranjon の司会ですぐ Houdremont Lecture の Discussion が始まった。 4 件の回答書を壇 上の木原教授に渡し, Discussion の最中にあと 1 問の 回答書を作成した．これは炭素当量に関するあので，木 原教授の指示で私自身演壇に立って黒板をつかって説明 した. そのほか, 日本の水素量の測定方法について屯黒 板に図示し説明した（写真一 -3 ). 応力除去焼なまし時 の割れの問題は, 京都大会で石川島播磨の内木氏から Commission IX へ論交を提出してもらうよう推せんし た.

京都大会の特別講演は、Portevin Lecture が行なわ れる年で, チェコスロバキヤの Prof. Cabelka に決定 している，乙のテキストについては, IIW 事務総長の

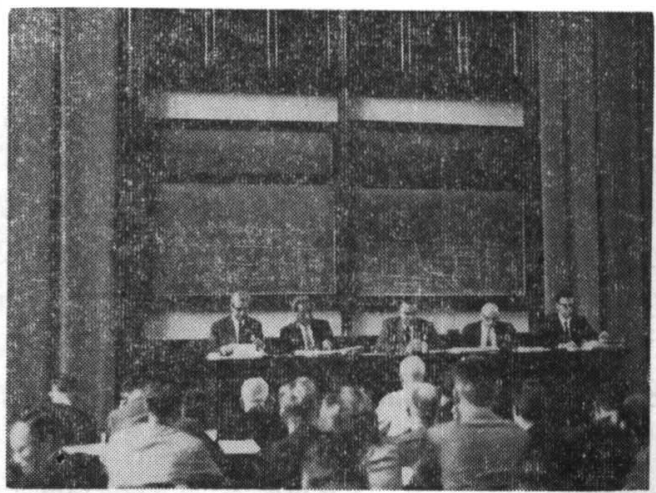

写真一 3 Commissions IX と X の Joint Committee における Houdremont Lecture の Discussion （黒板の字と図は著者の説明時に書いたもの）

P.D. Boyd から小林教授への 1968 年 7 月 17 日付の手紙 にあるように，テキストの翻訳と編集は従来 IIW 事務 局の責任になっているので, Prof. Cabelka のテキスト 原稿を IIW 事務局に送付すれば,むてうで翻訳してく れる，そしてそのテキストは京都大会での登録時または 講演開始時に出席者に配布される.

Portevin Lecture は所属の Commission がないの で, 当日の講演の司会は IIW 会長の Plummer 氏自身 が行なうととになっている. 京都大会ではワルシャワ大 会の例を感案して,プロジェクタとスクリーン, 講演用 の卓上ランプ, ランプ付指示棒, 同時通訳のための設 備, 場内マイクなどの小道具類の設営や通訳, プロジェ クタ担当者, 指揮連絡者などの人の問題についてじゆう 分考慮し, その場になってあわてないように準備と訓練 が必要である.

\section{5 公開討論会 (Public Session) について}

これは大会開催国の意志と Governing Council の承 認によって決定される. 大会主催国は大会招へいの申し 出をするときに，その大会に公開討論会を含めるかどう かを申し出ることになっている. 公開討論会の主題は 主催国が大会18 ケ月前までに IIW 事務局を通じて提案 し, Executive Council と Governing Council の議を 経て決定される. 論交募集と審査, 討論会議長および reporters の選任は主催国が行なうことになっている. 公開討論会に提出する論交は, そのときの主題について 4 論文までを原則とし国を代表する論文として会員国代 表団から提出されねばならない，提出された論文は主催 国が審査して採否を決定し,採択されたあのが reporters によってまとめられて発表され，そのあとで討論され る. 発表論文は全論文をまとめて印刷され出版される. この論文は大会の members に少なくとも大会のはじま る 6 週間前に配布しなければならない, 
ワルシャワ大会に括けるPublic Session は，木原教 授の Houdremont Lecture が終って昼食後 14 時から 同じく National Philharmoninc Hall で開かれたが, 出席者が午前にくらべて急激に減り 140 人ぐらいであっ た.その主題は “Welding in the Construction and Maintenance of Equipment for the Chemical Industry" で，副主題として3つの Groupにわかれ，

Group 1 ; Metallurgical problems in the welding of steels, non-ferrous metals and alloys for equipment for the chemical industry

Group 2; Problems in protection against corrosion

Group 3; Shop and site welding of equipment for the chemical industry

であった. 各 Group の諭文の数は, Group 1 が 8 件, Group 2 が 5 件 (うち日本から 2 件), Group 3 が 5 件 (うち日本加ら 1 件)，計 18 件（うち日本 3 件）であっ た. 討論会議長はオランダの Mr. W.P. Kerkhof, Secretary はポーランドの Mr. E.A. Juffy で, 各 Group ご との reporters（ポーランド 3 人）が 15 20分で一括発 表しついでそれぞれ討論に入る仕組みになっている．討 諭は議長の Mr. Kerkhof が 1 人で処理していたが，比 較的低調で，質問の件数が少なくわが国からの 3 件につ いては一つも質問がなかった。むし質問が日本にあった とすれば，予告なしの場合相当当惑したてとであ万うと 思われる。楌諭会ははじめ Circular No. 2（1968年 1 月）の案内では，15日（月）Group 1，2，3および16日 (火) Group IV とVkなっていたが, 大会当日の案内 書 (Programme) Kは15日（月）Group 1, 2,3 を14時 加ら19時まで行なうことになっており，16日は開加れな かった. しかも質問が少なかったせいか, 予定よりあ早 く17時でろには終ってしまった。私は16日も開かれると 思って,わざわざ National Philharmonic Hall へ出か けて行ったが，会場は閉っていてなんの揭示も出されて いなかった，あとで Programme を見て，16日の予定が いつの間にか消えていたてとを知ったのである。

京都大会では日本が意志表示をしたので，つぎの議題 でPublic Session を開くととになった。

主 題: “Use of High-Strength Materials in Welded Construction"

\section{副主題 :}

(1) Theoritical background to development of high-strength materials for welding

(2) Present trends and future prospects for high-strength materials for welding

(3) Problems in the welding of high-strength materials
(4) Problems in designing welded structures using high-strength materials

(5) Examples of welded structures using high:strength materials.

京都大会の Public Session では1国 3 論交までとし， 諭文概要申込みみ゙切1968年10月1日，本論文み切1968年 12月31日，採否決定1969年 1 月15日以降，論文配布1969 年 4 月15日ということで計画を進めている。1968年10月 現在各国から日本屯含めて电迟みが12件きている。いう までもなく討論会であるから，活発な討論が行なわれる

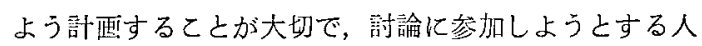
は前もって主催者に通知しなければならないが，てれだ けを待っていると討論参加者が少なく低調になるおてれ がある.したがって，主催者はあらかじめ国内で討論者 を積極的に指定して扰く準備も必要であろう. 当日はと くに，技術的な傠論を正確に翻訳する能力のある通訳を 選定し，同時通訳を行なうことが希望される。また討論 の永久記録が必要なので，討論者加ら後で討論内容を文 書であらうかあるいはテープレコードをしておくてとむ 大切である、なお，討論会の議長として Mr. H. Granjon が候補に上っているが，彼も諭文を提出したい上うな ので，人選に檢䚯を要するであるう。その後 Mr. N. Granjon から承諾の通知があり，議長は彼にきまった。

\section{6 技術委員会 (Technical Commissions) につ いて}

技術委員会は前にあ少しふれたように，IIWに括ける 技術的な問題を討議する本体となる定常的な委員会で ある. 16 の委員会がAとBの 2 Group にわけられ，午 前之午後にわかれて会合する. 午前之午後によ゙ちらの Group が開催されるかは年によって変更されるが，午 前传委員会を開催した Group は午後に，午後に会合し た Group は翌日の午前にそれぞれ議事録の起草委員会 (Drafting Committees) を開催する. 委員会での決議事 项各条員会の会期最終日の夜まとめられて Executive Council に提案される. な打てれとは別に Study Group として212委員会 (Physics of Welding Arc) があり, 会期中適当な時間比別の会議室で会合している.

各委員会はその主題にしたがって調查, 試験および共 同研究，各個研究発表を実施している，てのため各委員 会は随時必要比伈じて間会議を開いている，年次大会 では総括的な会合を開き，年間の活動報告や計画の決 定，それに研究発表を行なっている. 各委員会に提出す る論文は, 日本の場合，IIW、比対応する JIW の各委員 会で検討の上, JW の各委員長がその年の出席者名簿之 論文概要を IIW のそれぞれの委員長にあらかじめ㺺送 して了承を得, 各論交の Document No. をむらう。” 
の後各論文提出者は IIW の各委員長からの指示にした がって，本論文を大会開催前の定められた期限までに各 国へ送付する. 提出論文の内容は各委員会の活動や計画 にマッチしたものが望ましい，そしてまた，年次大会の 準備として開加机各委員会の中間会議（多くの委員会 ではその年の初めの 1 月または 2 月ごろに開かれる)に 間に合うように委員長にできるだけ早く連絡をとると都 合がよい.日本の JIW の各委員会では常時 IIW の対応 委員会之連絡をとり，IIW からの技術的なアンケートな ぞに回答したり，その他の指示に対処している.したが って本来各個人は JIW の委員会を通じて常時 IIW の関 係委員会に接触し，必要な作業に参加協力してほしいる のである. 委員会での作業結果は，それぞれの分野によ って他の国際機構へ提案され，また会員各国への勧告が なされたりして，国際的にまとまった結諭として活用き れる。

ワルシャワ大会の技術委員会は, ワルシャワ大学の各 講義室で, Group A の Commissions が 7 月 16, 17, 18, 1904 日間，14洔～17時，20日（土）は. Commission I だけが 9 時〜 12 時關催され、Group A の Drafting Commsttees が17，18，19，20日の 4 日間， 9 時〜12時行 なわれた。一方，Group B は反対に Commissions がそ れぞれの日の午前 9 時〜12時, Drafting Committees が 午後の 14時〜17時行なわれた。なお，212委員会は17日 午前, 18 日午前之午後, 19 日午前と午後, 20 日午前之都合 6 回開かれた. 各 Commission によって議事の進行がい くらか異なるが，あらかじめ議題と日時予定が各出席者 に通知されており，大体それにしたがって進められる。 個人論文については著者が数分で概要を説明しつづい て討論する場合，はじめから討諭に入る場合あるいは Chairman などが一括報告する場合などがある。公用語 は英語と仏語であるので，そのいずれかで話をするとと になるが，同時通訳は行なわれない，Chairman らはふ つう両国語ができ，必要に応じて両国語で同じことを説 明する．日本人の多くは当然傠諭がにが手であるが，岗 らかじめ想定される質問に対して答えられるよう，また 積極的に質問できるよう英作文を試みておき，臆病にな らずに「いうべきととはいうべきである」という信念を あっててとにあたる心構えが必要である. 討論は英語の 上手下手よりる慣れ之気概が大切である。

私は論文を Commission IX とXII にそれぞれ提出し たが，両 Commission が Group B 亿属しともに午前中 の同一時間に開催されたので，その日の議題によって は両方かけもちで出席した. Group A の午後の部では Commission XI 亿前年度提出した論文が未処理で質問 があるかも知れないらいうととなので 2 日間ほど出席し

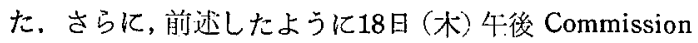
IX とX の Joint Meeting に屯出たので, めまぐるし く忙がしくじやっかん無理な状態であった。ふふつうは 1 つの Commission に一貫して出席するか，午前之午後 の 1 つづつの Commission に議題によって選択的に出 席するかのいずれかにすべきである，というのは，会期 中午前と午後に大体同心゙場所の工場見学が行なわれ，午 前の Commissions の Group は午後に工場見学し, 午 後の Group は午前に見学できるような仕組みになって いるからである.

京都大会の技術委員会の会合は，Group A が年前 9 時〜12時, Group B が午後の14時〜17時になっており, ワルシャワ大会とちようど反対で午前と午後が入れ変っ ている、したがっでDrafting Committees あ反対にな る。ただし，前述したように京都大会からは Group の じやっかんの編成变えがあり，Group A に新 Comm. IV が入り, Group B に Comm. VI が行くことになった.

Colloquium は技術委員会のなかのある Commission が中心となって，特別な会合として開催されるととがあ る.この場合はその Commissionの正規の会合時間の ほかにこの分だけ時間が追加され，会議室す1つ追加に なる。

ワルシャワ大会では Commission I が Colloquium を行い主題 “Welding by Thermo-Chemical or Mechanical Energy"で, Group 1 : Cold Welding-Percusion Welding-Friction Welding（論交数 9 件，亏5日本 2 件), Group 2 : Thermit Welding-Explosion Welding (論文数 6 件, うち日本 1 件), Group 3: Diffusion Welcing（論交数 2 件）に尔けてそれぞれ Reporter が 1 人づつついて17日（水）の14時一18時まで開催した.

場所は National Philharmonic Hall で, Chairman 兼 General Reporter は Commission I の委員長 Mr. M. Evrard (フランス) であった.

京都大会では Commission X が Colloquium を計画し ており, Chairman は Comm. X の委員長木原教授，CoChairman は Prof. Soete (ベルギー)で, 主題は“The Properties and Testing of Weld Metal in relation to Structural Failure from Brittle Fracture" である. 内 容は 1) Fracture Mechanics Approaches (論文予定 6 件，うち日本 4 件) reporter 金沢教授，2) Metallurgical Approaches（諭文予定 3 件，う古日本1件）reporter Prof. R.D. Stout, 3) General Aspects (諭文予定 3 件), そのほかさらに論文 5 件を現在考虑中，亡なっている.

3.7 レセプション (Reception), 宴会 (Banquet), 国別会合 (National Meeting), 催し物, 会期 中見学，会期後旅行と見学，Welding Show 
年次大会には各種会議のほ加に，参加者間の交歓と開 催国の事情を知ってすらうため標記のような各種の行 事が行なわれる。

\section{(1) Reception}

ワルシャワ大会では市長招待のレセプションが National Museum で月曜の夜 8 時から開かれた。到着 と同時に絵画を見てまわり，ついで立関から階段，ロビ 一のあたりに分散して立食いと飲酒. 主催者の掺摱もな くなんとなく見て食べて领んで帰った，飲物食物の量が 少なく参加者に行きわたらなかったようである。帰りは 折悪しくどしやぶりの雨となり，バスの配車むなく雨具 なしで雨にたたかれて引き揚げた，京都大会のレセプシ ヨン（日本学術会議会長招待）では，飲物，食物は恶 のあのでよいから量を多くしてもらいたいし，配車， Information などに気を配ってむらいたい子のである.

\section{(2) Banquet}

ワルシャワ大会の Banquet (IIW 会長招街) は Grand Hotel で木晴の夜 8 時から12時まで開かれた。会場が比 較的せまく 4 つぐらいの部屋に分離しており，また予約 席が多いために，思うように腰かけることができずまと まりの悪い会場であった，予約席の申し込みを何時受け つけたかまたどういう方法で行なったか疑問が多く，な かには予約席の奪い合いなど見にくい場面も見られた。

Show，は小人数のラテン風の踊りと歌であった．主会場 で組織委員長，IIW 会長などの挨摱があったが，隣り会 場にいた人々は主会場で何が行なわれているかわからな いような状態であった。

\section{(3) National Meeting}

ワルシャワにおける日本の Natiọnal Meeting は金嚁 夜 7 時から Palace of Culture and Science $の$ 高層ビル 1 階のロシャ料理店 “Troyka”で行なった，日本人出席 者のほぼ全員的 40 人が参加し，開放された気分で愉快に 過した。

\section{(4) 催 し 物}

ワルシャワ大会の催し物としては, Grand Theatre て 火曜の夜 8 時加ら10時すぎまでの民族舞踊と水曜の夜 8 時から10時半までの才ぺラがあった．広場の1角にある ヨーロッパです2番目に大きいといわれる壮大な国立劇 場で，乙くに民族舞踊はすばらしかった．すべて指定席 になっており，私は数人の日本出席者ととあに幸運にも 楽団のすぐ後ろの最前列中央の席であったので，多人数 の群舞之合唱に大変な迫力を感じた．京都大会では日本 伝統芸能として，都掞ら゙りが考えられているが，果して 参加者に感銘を与えるかどうか検討が必要であるう。

\section{(5) 旅行亡見学}

ワルシャワ大会では会期中の参加者の工場見学，同伴
者の Sightseening が恒例によって行なわれた. 私は Commission の会議が仙しくて，会期中の工場見学は 予定を変更して 1 个所 “Huta-Warszawa” 特殊 鋼工場 だけの見学によよ゙まった. 会期後の旅行と見学 (Post Assembly Tour) にも加わらなかった. Post Assembly tour には A, B, C の 3つのコースがあり，日本の出席 者のなかでは仲，小林，成田，立木の諸氏が参加された そうである. 聞くところによると，コースによってはか なりの強行軍で参加者の疲れが目立ったそうである，日 本の場合，旅行や見学と見物を通じて日本の実情を認識 してもらい，また楽しい旅ができるよう紐かい配慮がほ しい，たとえば，日本の署い夏のことであるから冷房に 心がけ，無理のないゆったりとしたスケジュールが望ま しい．また日本の古いものよりもむしろ近代的な施設や 工業を知ってすらう方がよいと思われる。

\section{(6) Welding Show}

ワルシャワ大会では会期中，ポーランドの溶接譏器展 を工業大学の講堂内で開催していた。私は木曜の午後 4 時ごろ, ワルシャワ大学から配車のミニバスに乗ってて れを見に行ったが，1目で見わたせるほどの小規模のも ので，1時間たらずで見学することができた．展示され ている機器は標準的なかつ簡易なものが多かった。日本 の場合，東京晴海で国際的な Welding Show を花々し く計画しているようで，その成果を期待している注．

\section{4. 京都大会への期待}

队上のように，IIW の奉体にふれながらワルシャワ大 会を通じて見た京都大会への期待を述べた.

京都大会では外国加らの参加者として28ケ国約500人， 国内加らの参加者約 700 人計約 1200 人を想定しており， そう派手にやる必要はないが，親切で節度をむちそして 国内外によろこばれる大会にしたいものである。

大会には物質的な面と精神的な面があると思う．京都 大会組織委員会の運営費しして，国費 950 万円，募金委 員会交付金 3,400万円，溶接学会負担金 300 万円，大会 出席登録料 550 万円，合計 5,200 万円の予算額で行なわ れる.乙の額はワルシャワ大会と比較してやや少ない額 である．もし物質的な面で不足があったとしても，精神 的な面でできるだけカバーするように心がけねばならな W.

京都大会を通じて，わが国と諸外国の溶接関係の科学 技術の情報を交換し合い，わが国の溶接関係の国際的な

注）ワルシャワ大会の模様の写真は、すでに本誌， 1968年 9 月号の写真卜ピックスに揭載されている ので，参照されたい．ここではそれ以外の写真を 揭載した。 
認識と地位の向上をはかり，国内の研少態樊とその実施 に対する指針が得られ，また国際的な個人，研究機関， 会社，学協会などとの緊密な連絡が得られることを期待 するあのである.

わが国で IIW 年次大会を開催することははじめての
ことであり，短日時の間にもりたくさんの諸行事を川滑 に遂行しなければならないので, 関係者の熱意と努力之 細心の注意が要望される．関係者各位の絶大な御協力を 期待し，京都大会が無事成功するよう新ってやまないし だいである。

\section{IIW 第22回年次大会組織委員会活動報告*}

成田团郎**

\section{1. 組織委員会の設立と活動}

IIW 京都大会の準備活動は, 昭和41年12月に準備委員 会が設立され，その下に実行委員会をはじめとする下部 組織が作られて実際の活動を行なってきた。昭和 43 年 5 月に, 学術会議の中に IIW.第 22 回年次大会組織委員会 を設置するととが閣議で決定され，こてに正式な組織委 員会が生まれるとととなった。

IIW 第22回年次大会組織委員会は 5 月22日に第 1 回の 会合を開き，それまでの準備委員会の業務を引きつぐと ともに，新らしく規約，細則，役員を決定して活発な京 都大会の組織活動を行なうこととなった，組織委員会の 構成は表一1に示すとおりである.さらに，組織委員会 の効率的活動をはかるため, 組織委員会の中に幹事会が 設けられることとなった。

第 2 回組織委員会は 8 月 9 日に開加れ，小林運営委員 長（ワルシャワ大会日本代表団長）からワルシャワ大会 の報告を聞き，京都大会については，正規の登録料を 35 ドルとするととを決定し，また Circular No. 1 を承 認した. さらに, Circular No. 2 については, 運営委 員会にその準備を一任するととを決定した，連営委員会 の活動については別項で記述させていただく.

実行委員会は昭和 43 年 3 月に準備委員会の下に設置さ れ，第 1 回の委員会が開かれた. 同委員会は組織委員会 の設立とともにその下に入り，43年10月23日には第 2 回 委員会を開き, Circular No. 2 の運営委員会案を修正 承認した。

また，組織委員会の会務を円滑かつ迅速に遂行するた め, 組織委員会の中に幹事会が作られ，

各実務機関の調整

委員長の諮問事項代関する必要事項

その他組織委員会の会務統括に関する必要事項を審 議実施することとなった．

組織委員会, 実行委員会および運営委員会の名簿は次

*原稿受付 昭和43年11月 4 日

**禾 只 日本鍓管(株)技術部
頁以下の表に示すとおりである。

\section{2 . 年次大会の準備経過}

運営委員会の昭和 42 年度までの活動については, すで に本誌43年 1 月号に述べられているが，昭和 43 年に入っ てからはさらにその活動を強化し，準備委員会および象 行委員会の方針にしたがって多くの作業を実施した。乙 れらの作業は, 運営委員会, 総務担当打合世会, 各小委 員会あるいは関西侧との連絡会議等の会合によりまた 運営委員会および各小委員会委員の精力的な行動によっ て進められた.

まず，IIW 年次大会の正規なあり方を確認するため， すでに昭和 41 年から IIW 年次大会組織比関するメモう ンダムを基礎として検討を進めてきたが，亡れに関連し た問題点をひろい出し，その内容について小林運営委が ボイド事務総長と会談することとなった.小林委員長は. 2 月20日, IIW 第XII 委員会の Intermediate Meeting に参加の途上ロンドンにボィド事務総長を訪問し，多く の有益な情報をえた。

京都大会のための Circular No. 1 (登録, 理事会, 執行委員会, 開会式, 特別講演, 公開討論会, コロキウ 厶, 技術委員会, 起草委員会などの日程, 時間割り) は，実行委員会および組織委員会の承認をえて原案を準 備した. この原案はワルシャワに执いて, ボイド事務総 長招よびルロア科学技術書記に手を入れてもらって英仏 両国語のものを完成し，9月に印刷され，各国に発送さ れた.

ワルシャワ大会においては，小林運営委員長，渡包学 術会議事務局次長, 成田・立木運営委員がボイド事務総 長に合い, Circular No. 2（大会㧍よび付带行事の計画 書) の立案の問題をはじめとして，京都大会準借に関す る打合せを行なった．このほか，ポーランド組織委員会 のスタッフであるワイナロウスカ夫人らに会い，登録業 務の害態についてワルシャワ大会の情報を得るととがで きた.

また，同様ボイド事務総長およびポーランド組織委員 